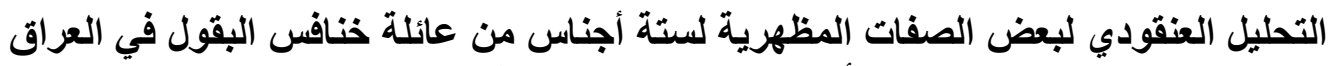

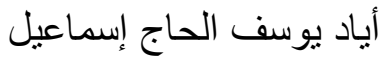

قسم علوم الحياة كلية التربية للعلوم الصرفة جاجة إمعة الموصل العراق

Email: aeadhajismail@gmail.com

\begin{abstract}
الخلاصة
تضمن البحث التصنيف العددي للأجناس الحشرية الستة التابعة لعائلـة خنافس البقول من رتبـة غمديـة

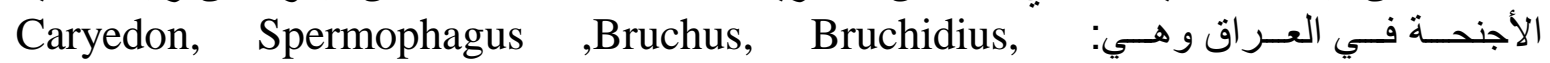
Callosobruchus, Acanthoselides ,(Family Bruchidae, Order Coleoptera)

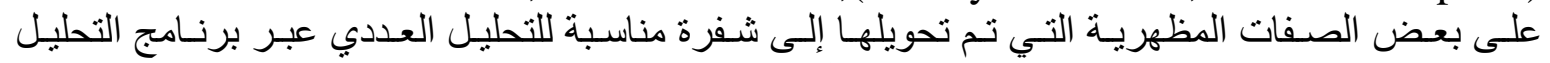
الإحصائي الجاهز SPSS -17 وقورنت بواسطة الحاسوب لتعين درجات القرابة وبينت النسبة المئوية للصـلة الشعبية على أساس درجة التشابه لبعض للصفات المظهريـة وبلغت

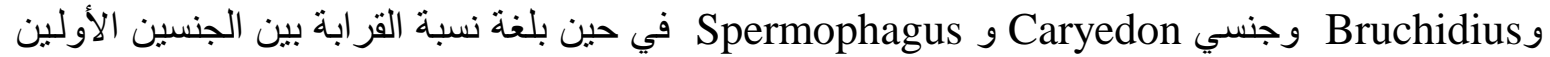

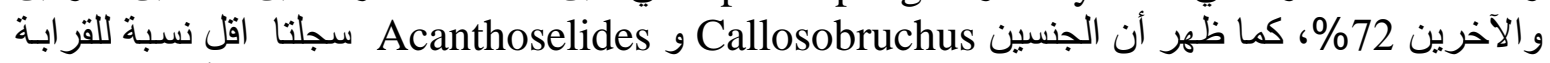

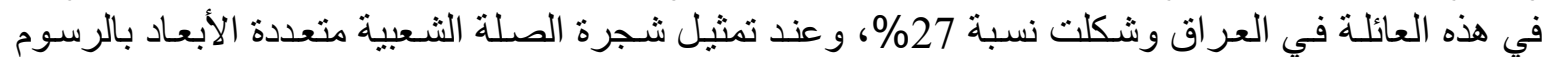

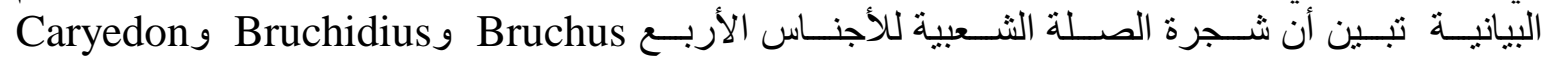

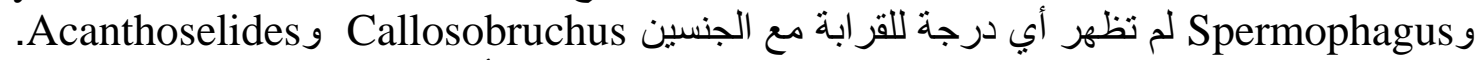
الكلمات المفتاحية: التصنيف العددي؛ التحليل العنقودي؛ رتبة رئة غمدية الأجنحة؛ عائلة خنافس البقول؛ العراق.

\section{المقدمة}

عرف التصنيف العددي أو التصنيف التدريجي أو التسلسلي

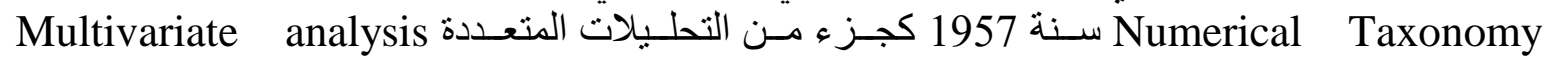
(1957,Sneath)

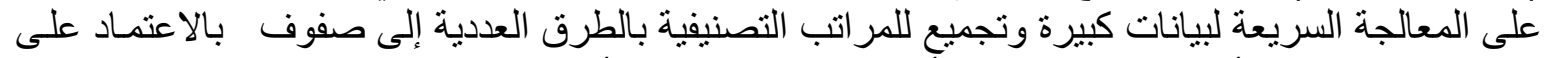

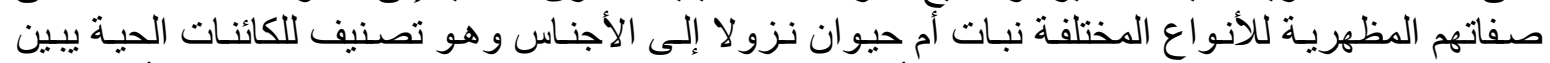

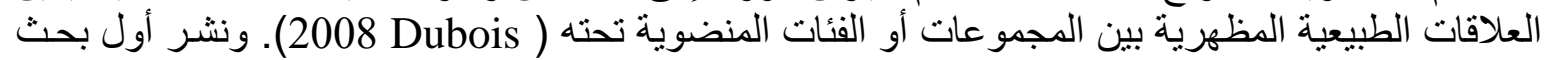

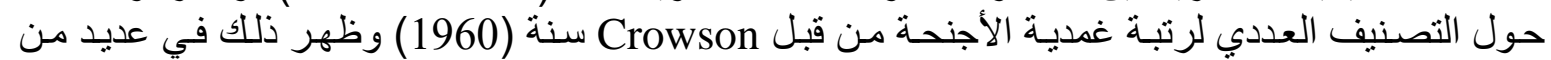

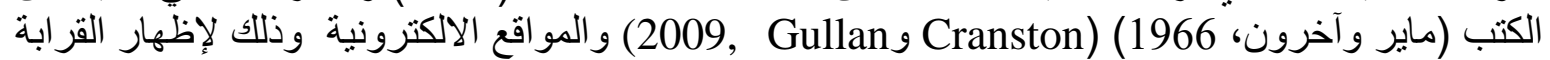

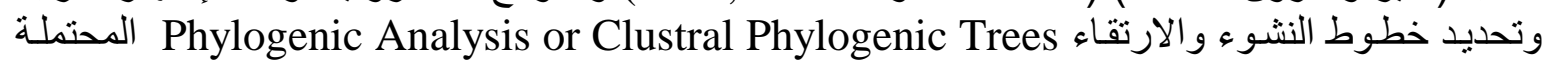

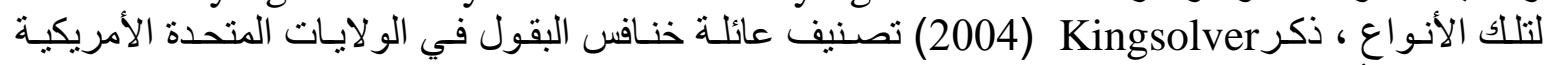

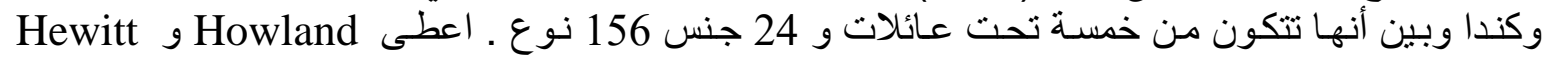

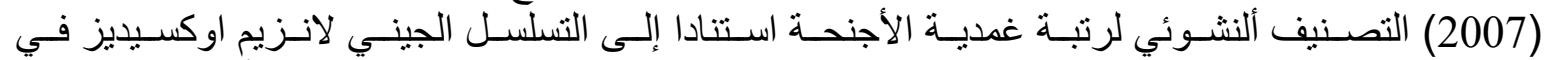

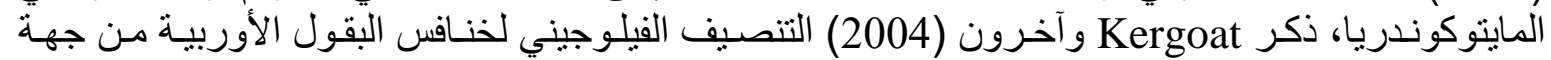

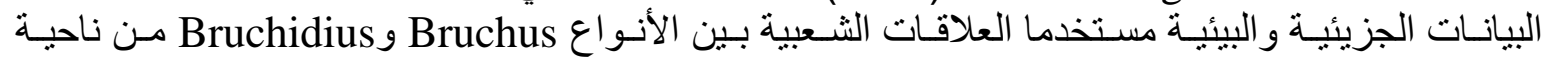

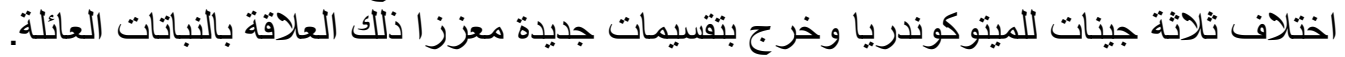

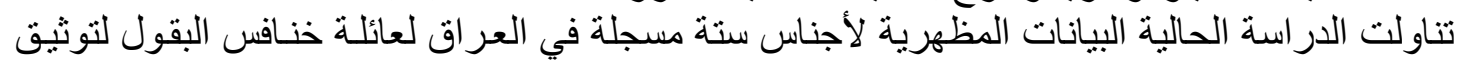

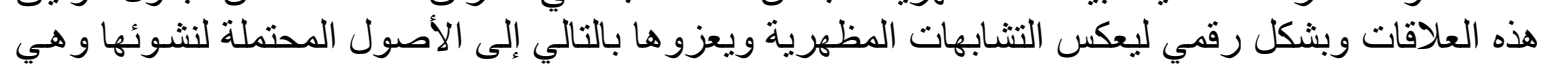

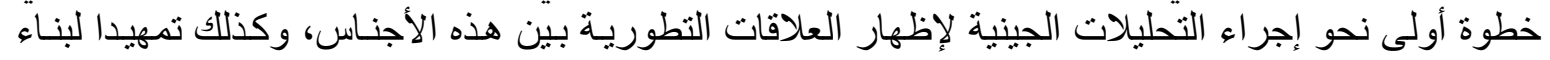
قاعدة بيانات للتصنيف الآلي لهذه التهرة العائلة. مواد البحث وطيانث وطر ائقه

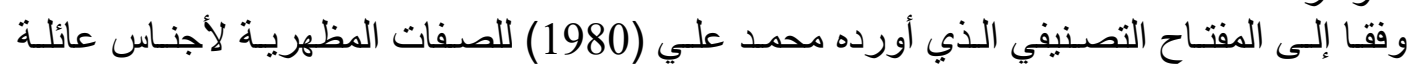

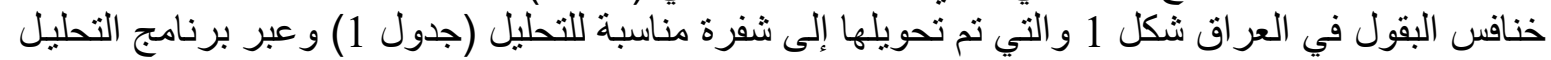

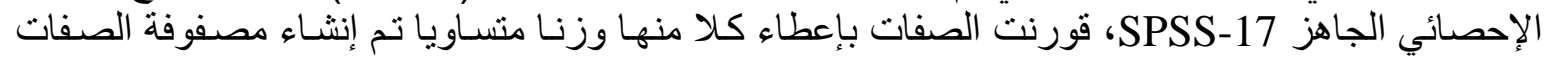
المظهرية للأجناس الستة لعائلة خنافس البقول في العراق (Family Bruchidae: Order Coleoptera)

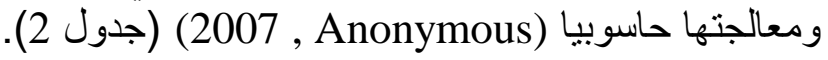


Mesopotamia J. of Agric.

Vol. (46) No. (4) 2018
ISSN: 2224 - 9796 (Online)

ISSN: 1815 - 316 X (Print)

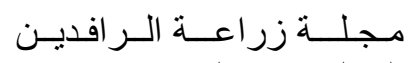
المجلد (46) العدد (4) 2018

\section{النتائج والمناقشة}

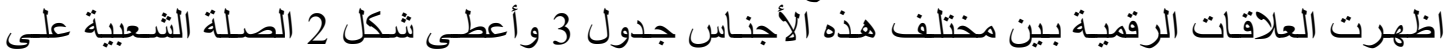

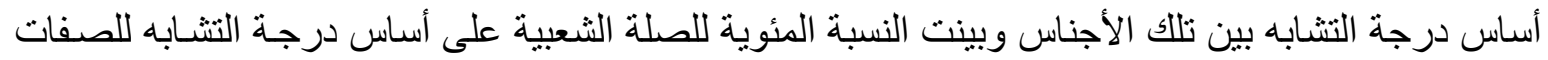

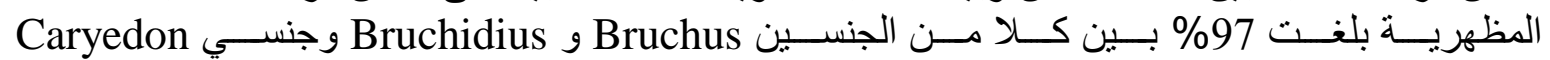

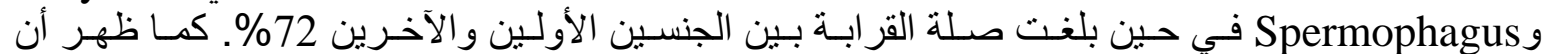

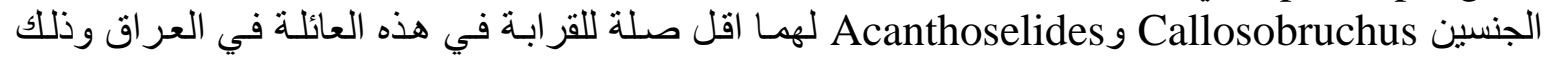

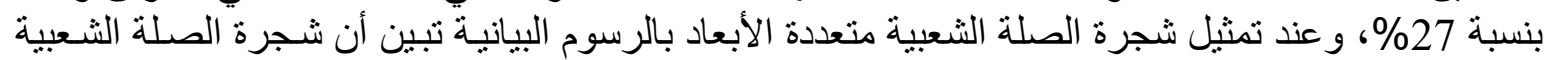

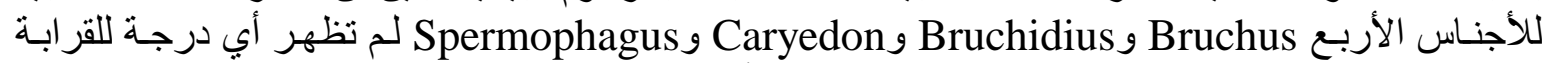

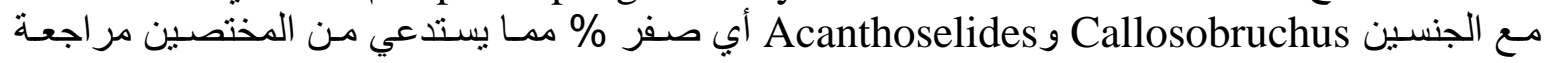
ذللك،

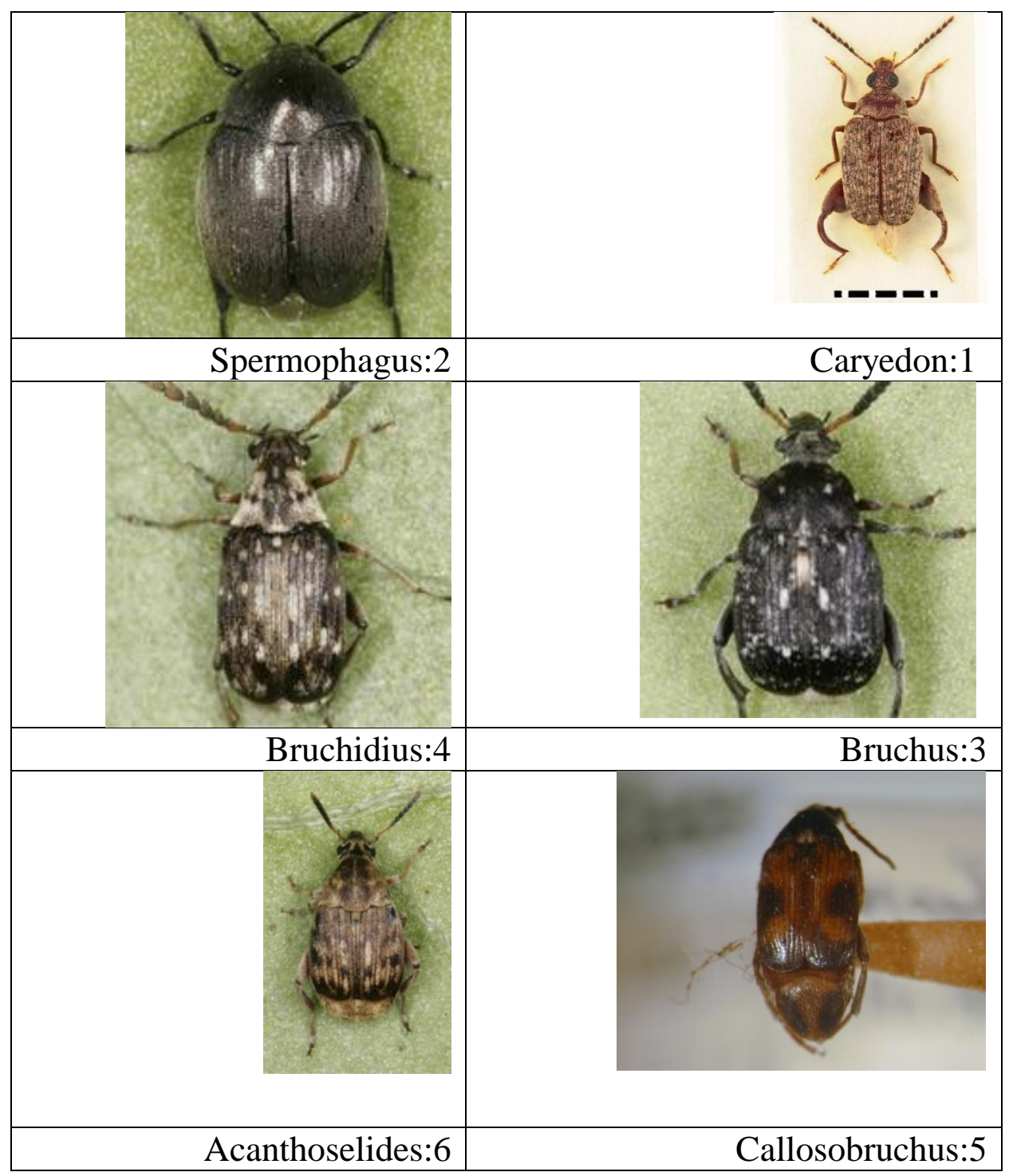

الأرقام المجاورة للأسماء تدل على تسلسل ذلك الجنس في جدول 2.

*Numbers behind names indicated sequence of this genus in Tab 2.

$$
\text { شكل (1) صور أجناس عائلة خنافس البقول في العراق. }
$$

Fig (1) Photos of the family Bruchidae genera in IRAQ. 
أن تلك الصفات المظهرية موضحة بالثكل 3 ويبين مقدار المساحة التي يشـلها كل جنس من هذه الأجناس

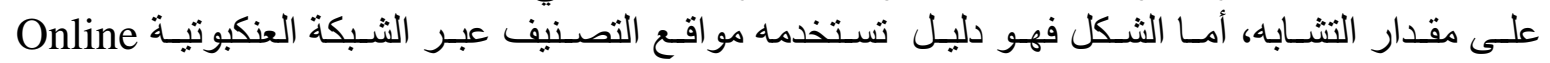
Taxonomies

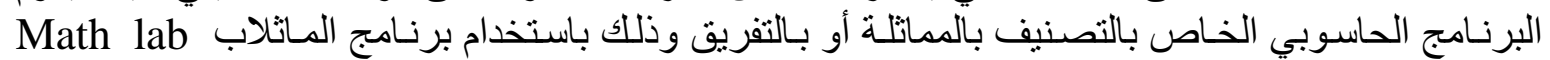

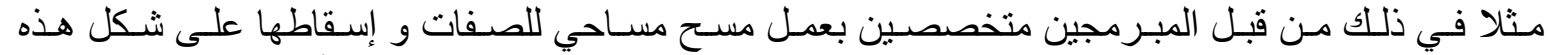
المساحات للاستدلال على الاسم و عند عدم التطابق فقد يكون جنس جديد لهذه العائلـة أو قد يعود إلى عائلــة

أخرى(2005، Houcque).

جدول(1) الصفات المظهرية المنتخبة للصدات الثعبية في التصنيف العددي لأجناس عائلة خنافس البقول في العراق

Table (1) The selected morphological characteristics of popular relations in numerical taxonomy of Bruchidae family genera in IRAQ.

\begin{tabular}{|c|c|c|c|}
\hline الشفرةCode & التفصيلات Specialties & الصفات Characteristics & Series \\
\hline $\begin{array}{l}1 \\
2 \\
3\end{array}$ & قلا يحوي هذه التحزز & 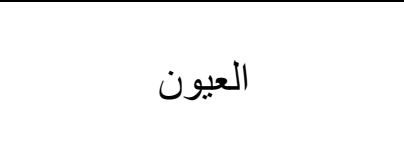 & 1 \\
\hline $\begin{array}{l}1 \\
2 \\
3\end{array}$ & لا بحوي هذه الصفة & 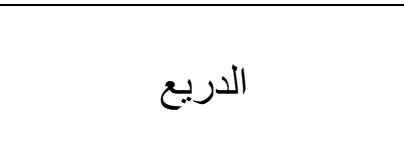 & 2 \\
\hline $\begin{array}{l}1 \\
2 \\
3\end{array}$ & الأمامي شيبه هذه الصفة & الصدر & 3 \\
\hline $\begin{array}{l}1 \\
2 \\
3 \\
4\end{array}$ & 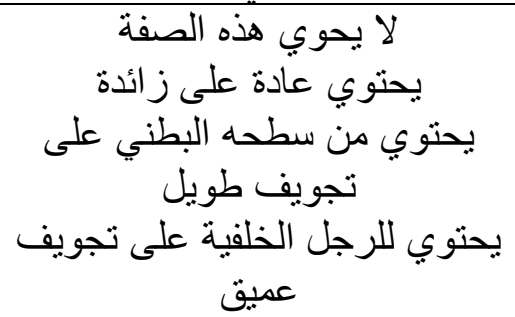 & 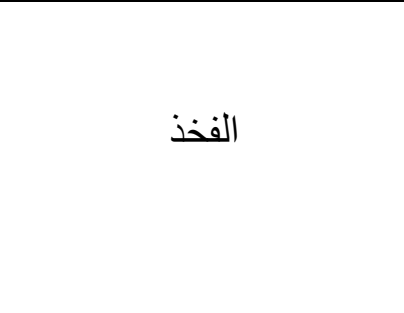 & 4 \\
\hline
\end{tabular}

جدول(2) مصفوفة الصلات الثعبية للتصنيف العددي لأجناس عائلة خنافس البقول في العراق

Table (2) Popular relations matrix of the morphological taxonomy of Bruchidae family genera in IRAQ.

\begin{tabular}{|c|c|c|c|c|c|}
\hline \multicolumn{4}{|c|}{ الصفات Characteristics } & \multirow{2}{*}{ الأجناس } & \multirow[b]{2}{*}{ Series } \\
\hline 4 & 3 & 2 & 1 & & \\
\hline 1 & 1 & $* * 1$ & 2 & Caryedon & 1 \\
\hline 1 & 1 & 2 & 3 & Spermophagus & 2 \\
\hline 1 & 2 & 3 & 3 & Bruchus & 3 \\
\hline 2 & 3 & 3 & 3 & Bruchidius & 4 \\
\hline 3 & 3 & 3 & 3 & Callosobruchus & 5 \\
\hline 4 & 3 & 3 & 3 & Acanthoselides & 6 \\
\hline
\end{tabular}

*Value No. 1 means that this genus does not • • لقيمة العني لا يملك هذا الجنس هذه الصفة.| have this characteristic.

**Numbers of characteristics indicate the . الأرقام للصفات تدل على تسلسلها في جدول 1** sequence of in Table 1 
Mesopotamia J. of Agric.

Vol. (46) No. (4) 2018
ISSN: 2224 - 9796 (Online) ISSN: 1815 - 316 X (Print)

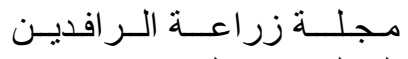
المجلد (46) العدد (4) 2018

جدول (3) مصفوفة نسب التشابه والاختلاف في المر اتب التصنيفية لأجناس عائلة خنافس البقول في العراق Table (3) Proximity matrix of Family Bruchidae genus in IRAQ

\begin{tabular}{|c|c|c|c|c|c|c|}
\hline Case & \multicolumn{5}{|c|}{ Correlation between Vectors of Values } \\
\cline { 2 - 7 } & $\begin{array}{c}\text { 1:Caryed } \\
\text { on }\end{array}$ & $\begin{array}{c}2: \\
\text { Spermoph } \\
\text { agus }\end{array}$ & $\begin{array}{c}3: \text { Bruch } \\
\text { us }\end{array}$ & $\begin{array}{c}4: \text { Bruchi } \\
\text { dius }\end{array}$ & $\begin{array}{c}\text { 5:Callos } \\
\text { ob. }\end{array}$ & $\begin{array}{c}\text { 6:Acanth } \\
\text { os. }\end{array}$ \\
\hline 1:Caryedon & & .870 & .522 & .333 & .000 & -.333 \\
\hline 2:Spermophagus & .870 & & .818 & .522 & .000 & -.522 \\
\hline 3:Bruchus & .522 & .818 & & .870 & .000 & -.870 \\
\hline 4:Bruchidius & .333 & .522 & .870 & & .000 & -1.000 \\
\hline 5:Callosobruchus & .000 & .000 & .000 & .000 & & .000 \\
\hline 6:Acanthoscelides & -.333 & -.522 & -.870 & -1.000 & .000 & \\
\hline
\end{tabular}

*This is a similar matrix. هذه المصفوفة متماتثة *

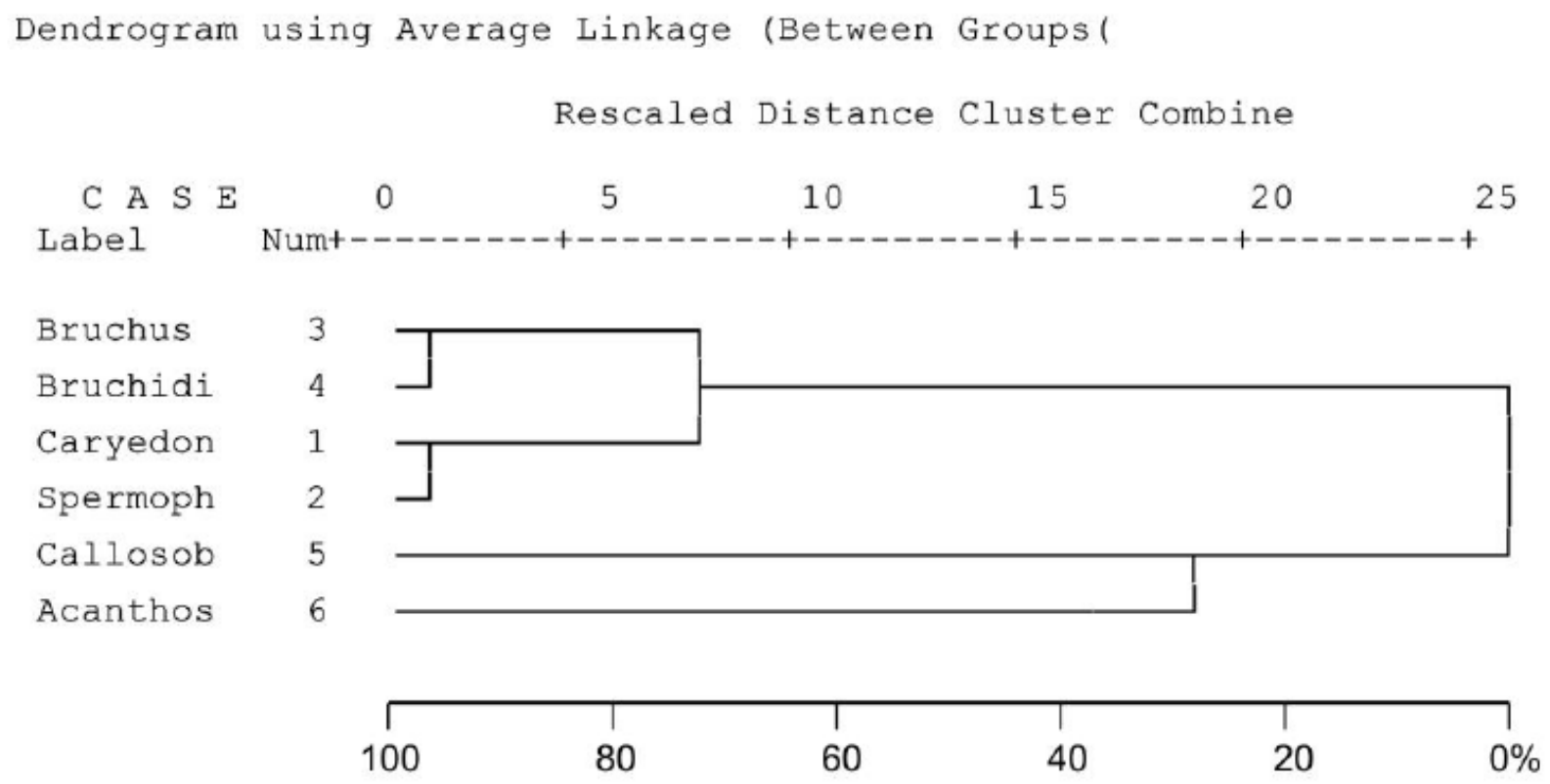

الأرقام المجاورة للأسماء تدل على تسلسل ذلك الجنس في جدول 2.

${ }^{*}$ Numbers behind names indicated sequence of this genus in Tab2.

شكل (2) المخطط الثجيري لارجات التشابه و الاختلاف بين أجناس عائلة خنافس البقول في العراق.

Figure (2) Dendrogram of similarity and difference decrees between genera of Bruchidae in IRAQ. 


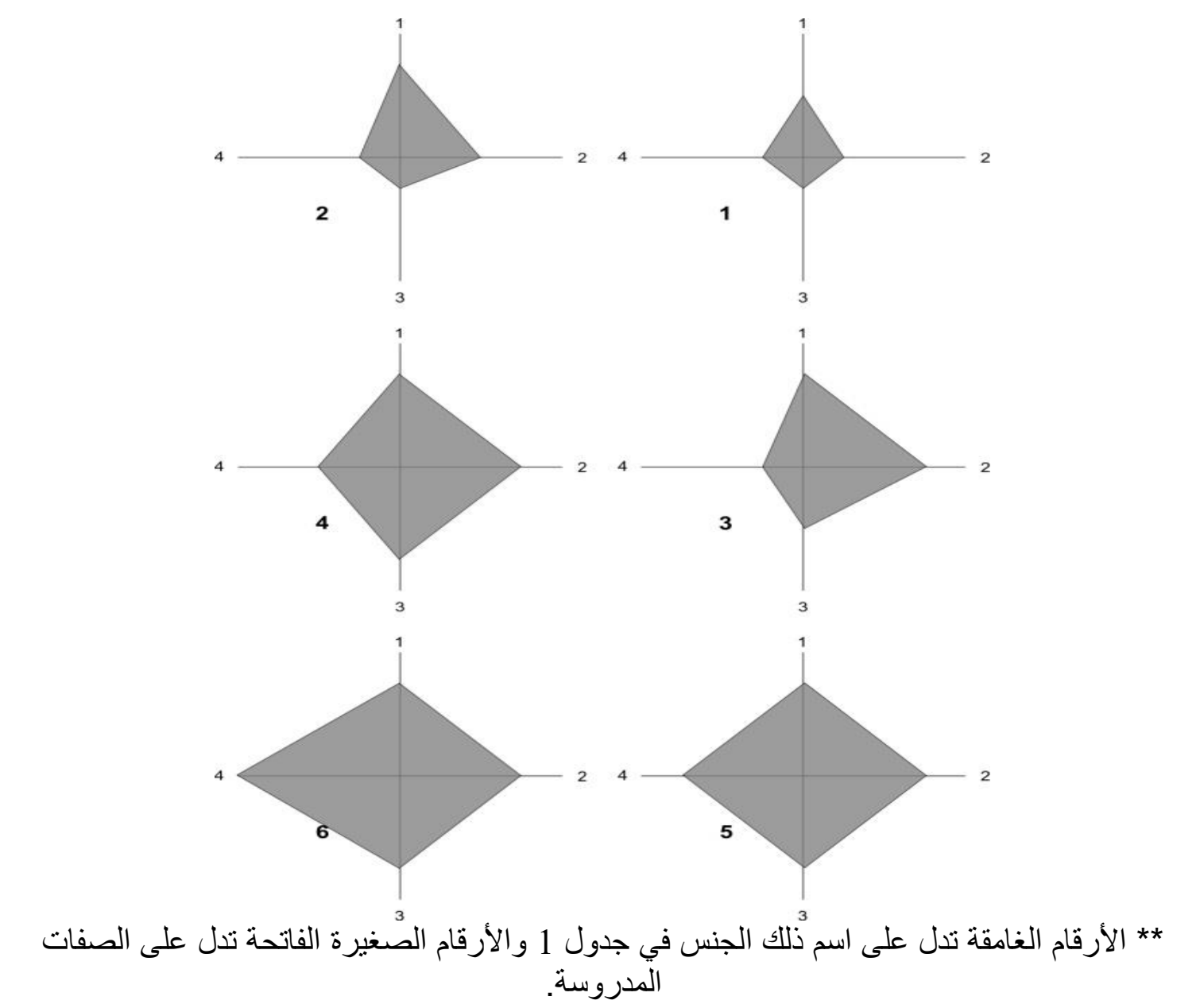

** Dark figures indicate the name of that genus in Table 1 and figures show traits. شكل (3) رسم عديد الأضلاع للصفات المظهرية لأجناس عائلة خنافس البقول في العر اق.

Figure (3) Multisided shape of morphological characteristics of Bruchidae genus in IRAQ.

\title{
GLUSTERING ANALYSIS OF MORPHOLOGICAL CHARACTERISTICS OF SIX GENERA OF BRUCHIDAE FAMILY: COLEOPTERA ORDER IN \\ IRAQ
}

Aead Y. Haj Ismail

Biology Dept., College of Education for Pure Science, Mosul University

Mosul IRAQ

Email: aeadhajismail@gmail.com

\begin{abstract}
The research tackles the taxonomy of six insects genera:Caryedon, Spermophagus, Bruchus, Bruchidius, Callosobruchus and Acanthoselides that belong to Bruchidae family :Coleoptera order which are recorded in Iraq depending on morphological characteristics which were given suitable code for numerical analysis by using clustering analysis statistically packaging SPSS-17. The results were compared by computer to manifest different kinship relations. The results manifest that the relation percentage of phylum is $97 \%$ on basis of the degree of
\end{abstract}


similarity of morphological characteristics between Bruchus and Bruchidius genera; and between Caryedon and Spermophagus genera, whereas the kinship relation between the former two genera and the latter two is $72 \%$, its reveals that Callosobruchus and Acanthoselides genera have less degree of relation $27 \%$ in this family in Iraq. By using diagrams of multisided popular relation tree it appears that popular relation of the four genera Bruchus, Bruchidius, Caryedon and Spermophagus have no kinship relation with the two genera Callosobruchus and Acanthoselides i.e. $0 \%$.

Key words: Numerical Taxonomy; Clustering Analysis; Coleoptera; Bruchidae; IRAQ.

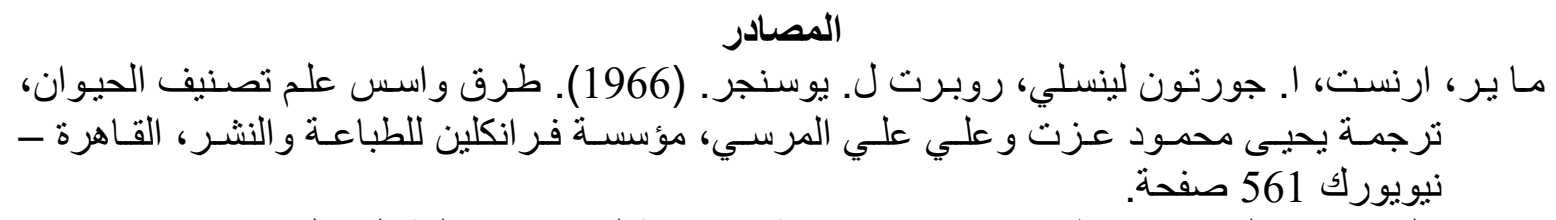

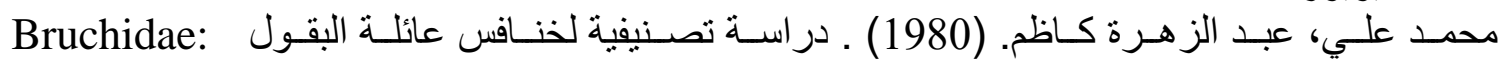
Coleoptera: Insecta

Anonymous (2007). SPSS Statistics Base .17.0, Users Guide. 616 Pages.

Cranston, Peter S. and Penny J. Gullan (2009).Phylogeny of Insects .Encyclopedia of Insects: 828-882.

Crowson, R.A. (1960). The Phylogeny of Coleoptera. Annu.Rev.Entomolo.5:111134.

Dubois, Alain (2008). Aphylogenetic hypotheses, taxa and nomina in Zoology. Zootaxa.1950:51-86

Houcque, David (2005).Introduction to Math lab for Engineering Students, Version1.2 .Northwestern = University .74 Pages.

Howland, D.E. and G.M. Hewitt (2007).Phylogeny of the Coleoptera based on mitochondrial oxidase I sequence data. Insect Molecular Biology.4 (3):496-507.

Kergoat. G.J.; A. Delobel and J.F. Silvain.(2004).Phylogeny and hostspecificity of European Seed beetles (Coleoptera, Bruchidae), new insights from molecular and ecological data .Molecular Phylogenetics and Evolution.32(3) 655-865.

Kingsolver, J.M. (2004). Handbook of the Bruchidae of United States and Canada (Insecta, Coleoptera).U.S. Department of Agriculture,Technical Bulletin 1912, Vol 2.,636.

Sneath, P.H.A. (1957). Some Thoughts on bacterial Calssification.J.G.Microbiol.17:184-200.1 